\title{
Pemetaan terumbu karang dengan citra satelit Sentinel-2 dan analisis kondisi karang di kawasan Pantai Pasir Putih, Situbondo Jawa Timur
}

\author{
(Mapping of coral reefs using Sentinel-2 satellite imagery in the Pasir Putih Beach area, \\ Situbondo, East Java and analysis on its coral conditions)
}

\author{
M. Arif Zainul Fuad*1, M. Fadilah Nur Ramadhani*, Citra Satrya U. Dewi*, M. Anwar \\ Fikri*, Edo Bagus Herdikusuma*
}

* Universitas Brawijaya, Jl. Veteran, Malang, Jawa Timur, 65145, Indonesia

${ }^{1}$ Corresponding author, Surel: fuad_maz@ub.ac.id

Paper received: 15-05-2021; revised: 20-09-2021; accepted: 03-01-2022

\begin{abstract}
This research was conducted in Pasir Putih, Situbondo district, East Java with the aim of mapping coral reef ecosystems and analyzing the condition of coral diversity to support learning Geography in remote sensing courses. Coral reef maps were extracted from Sentinel-2 satellite imagery by applying a water column correction algorithm. Mapping of coral reef areas resulted in 3 categories, namely live coral with an area of 32,860 $\mathrm{Ha}$, dead coral 31,690 $\mathrm{Ha}$, and sand 42,670 $\mathrm{Ha}$ with a level of 72.2 percent which is included in the good category. Testing the accuracy of the extracted map using the confusion matrix method based on 90 field survey data. The accuracy of the resulting map met the accuracy standard specified in SNI No. 7716:2011 for Mapping of Habitats in Shallow Sea Waters. Furthermore, coral reefs were observed in 20 locations using the Line Intercept Transect (LIT) method. The results showed that 13 of the 20 transect areas were found to be in poor condition with less than 25 percent live coral cover. The most common types of coral life forms found at the study site were Coral Massive, Acropora Branching, and Acropora Tabulate. Coral life forms that are very rarely encountered are Acropora Submassive and Coral Mushroom. This research is very relevant in remote sensing courses for learning Geography.
\end{abstract}

Keywords: coral reef mapping; Sentinel-2; coral diversity

\begin{abstract}
Abstrak
Penelitian ini dilakukan di Pasir Putih kabupaten Situbondo, Jawa Timur dengan tujuan untuk memetakan ekosistem terumbu karang dan menganalisis kondisi keanekaragaman karang guna mendukung pembelajaran Geografi pada matakuliah penginderaan jauh. Peta terumbu karang di ekstraksi dari Citra satelit Sentinel-2 dengan menerapkan algoritma koreksi kolom air. Pemetaan area terumbu karang menghasilkan 3 kategori yaitu karang hidup dengan luas $32.860 \mathrm{Ha}$, karang mati $31.690 \mathrm{Ha}$, dan pasir $42.670 \mathrm{Ha}$ dengan tingkat sebesar 72,2 persen yang termasuk dalam kategori baik. Pengujian akurasi peta hasil ekstraksi ini menggunakan metode confusion matrix berdasarkan 90 data survei lapangan. Akurasi peta yang dihasilkan ini telah memenuhi standar ketelitian seperti yang disyaratkan dalam SNI No. 7716:2011 tentang Pemetaan Habitat Perairan Laut Dangkal. Selain itu, pengamatan juga dilakukan pada terumbu karang di 20 lokasi dengan menggunakan metode Line Intercept Transect (LIT). Hasil penelitian menunjukkan bahwa 13 dari 20 area transek ditemukan dalam kondisi rusak buruk dengan tutupan karang hidup kurang dari 25 persen. Bentuk pertumbuhan karang yang ditemukan di lokasi penelitian dari yang terbanyak berturut turut adalah Coral Massive, Acropora Branching dan Acropora Tabulate. Bentuk pertumbuhan karang yang sangat jarang ditemui yaitu jenis Acropora Submassive dan Coral Mushroom. Penelitian ini sangat relevan dalam pembelajaran Geografi pada matakuliah penginderaan jauh.
\end{abstract}


Jurnal Pendidikan Geografi:

Kajian, Teori, dan Praktik dalam Bidang Pendidikan dan Ilmu Geografi

27(1), 2022, 73-87

Kata kunci: pemetaan terumbu karang; Sentinel-2; keanekaragaman karang

\section{Pendahuluan}

Terumbu karang adalah salah satu ekosistem pesisir yang menjadi sumber kehidupan bagi berbagai macam biota laut sehingga keberadaannya sangat dibutuhkan, baik dari sudut pandang ekologi maupun ekonomi (Nurhaliza, Muhlis, Bachtiar, \& Santoso, 2019). Perlindungan dan pengelolaan terumbu karang tidak hanya penting bagi habitat terumbu karang itu sendiri, tetapi juga bagi masyarakat lokal yang sangat bergantung padanya sebagai sumber daya alam. Fungsi Ekologi terumbu karang antara lain yaitu sebagi tempat berlindung, memijah (spawning ground) tempat mencari makan dan berkembang biak, tempat pengasuhan (foraging) bagi biota lain baik yang hidup di dalam terumbu karang maupun perairan sekitarnya. Terumbu karang memiliki nilai ekonomis karena dapat menjadi area penangkapan ikan dan dapat menahan gelombang sehingga dapat melindungi pantai dari abrasi. Berdasarkan penelitian tahun 2018 yang dilakukan oleh Lembaga Ilmu Pengetahuan Indonesia (LIPI) melalui Pusat Penelitian Oseanografi (P20), kondisi terkini terumbu karang di Indonesia umumnya dalam kondisi jelek sebanyak 386 site (36,18\%), kategori cukup sebanyak 366 site (34.3\%), kategori baik sebanyak 245 site (22,96\%), dan kategori sangat baik sebesar 70 site (6,56\%) (Hadi, Prayudha, Hafizt, \& Budiyanto, 2018).

Keanekaragaman terumbu karang dipengaruhi oleh habitat dan kondisi lingkungannya, termasuk interaksi biotik. Kondisi lingkungan yang berperan dalam keanekaragaman hayati terumbu karang adalah suhu air, salinitas, gelombang, arus, sedimen terlarut, yang umumnya sangat bergantung pada jarak ke muara sungai terdekat (Moll, 1986; Veron, 2002). Kondisi lain yang berpengaruh terhadap keanekaragaman hayati terumbu karang adalah kekasaran struktur kompleksitas dasar (Rugositas) terumbu karang (Edrus \& Hadi, 2020), substrat dasar, kedalaman, dan geomorfologi terumbu (Andrefouet \& Guzman, 2005; Moll, 1986; Veron, 2002).

Ekosistem terumbu karang terancam mengalami kepunahan. Hal ini umumnya disebabkan oleh pemanfaatan berlebihan terumbu karang oleh manusia baik langsung maupun tidak langsung serta pencemaran lingkungan. Gangguan antropogenik telah mengancam keanekaragaman hayati ekosistem ini. Terumbu karang merupakan sumber daya yang sangat penting, secara langsung dapat menghasilkan sumber makanan dan secara tidak langsung dapat menjadi daya tarik wisata (Akhmad, Purnomo, \& Supriharyono, 2018).

Pantai Pasir Putih di Situbondo merupakan salah satu tempat tujuan wisata bahari terutama wisata bawah laut di Jawa Timur. Perairan Pantai Pasir Putih memiliki terumbu karang yang indah sehingga menjadi tujuan aktivitas penyelaman untuk rekreasi maupun penelitian (Khusnah, Retnaningdyah, \& Kurniawan, 2019). Fasilitas olahraga air yang ada di lokasi ini sangat lengkap selain itu juga terdapat penginapan yang cukup mewah, ada cottage sebagai penginapan dan beberapa jenis rumah tinggal lainnya (Muthahharah \& Adiwibowo, 2017).

Keberadaan terumbu karang sudah menjadi daya tarik tersendiri bagi para penyelam. Namun demikian kegiatan wisata menyelam tersebut juga dapat memberikan dampak yang merugikan bagi ekosistem terumbu karang (Jubaedah \& Anas, 2019; Krieger \& Chadwick, 2013; Toyoshima \& Nadaoka, 2015). Oleh karena itu untuk mengurangi dampak dan untuk mempertahankan kondisi ekosistem terumbu karang tersebut, maka daerah Pantai Pasir Putih Situbondo telah ditetapkan menjadi daerah konservasi perairan dan telah ditetapkan dalam 
Jurnal Pendidikan Geografi:

Kajian, Teori, dan Praktik dalam Bidang Pendidikan dan Ilmu Geografi

27(1), 2022, 73-87

Peraturan Bupati Situbondo Nomor 19 Tahun 2012 Tentang Pencadangan Kawasan Terumbu Karang Pasir Putih Sebagai Kawasan Konservasi Perairan Daerah Kabupaten Situbondo (Pemerintah Daerah Kabupaten Situbondo, 2012).

Salah satu kegiatan yang sangat diperlukan dalam pengelolaan kawasan konservasi adalah identifikasi dan pemantauan kondisi terumbu karang (Cahyani, Setyobudiandi, \& Affandy, 2018; Jubaedah \& Anas, 2019). Pemantauan luasan dan kondisi terumbu karang dapat dilakukan baik dengan survei ekosistem terumbu karang maupun dengan teknologi penginderaan jauh (Hamylton, 2017; Hedley et al., 2016). Penginderaan jauh merupakan metode untuk memetakan habitat terumbu karang yang diintegrasikan dengan data lapangan untuk mengetahui kesesuaian dan validasi data. Ada beberapa informasi yang didapat dalam penginderaan jauh untuk memetakan terumbu karang, seperti reef extent, rugosity, coral vs makro algae, coral mortality, coral bleaching, dan bathymetry (Hedley et al., 2016).

Penelitian ini bertujuan untuk memetakan dan mengetahui kondisi terumbu karang dari kawasan Pantai Pasir Putih Situbondo, Jawa Timur dengan menggunakan citra satelit Sentinel2 dan survei lapangan. Penggunaan citra Citra Satelit Sentinel-2 pada penelitian ini terlebih karena ketersedian data yang dapat diunduh tanpa berbayar dan potensi kemampuan citra ini dalam pemetaan ekosistem pesisir dengan resolusi spasial yang lebih bagus $(10 \mathrm{~m})$ dibandingkan dengan Citra Landsat $(30 \mathrm{~m})$ yang umumnya digunakan dalam berbagai penelitian sejenis. Selain itu penelitian ini diharapkan dapat bermanfaat dalam pembelajaran pada mata kuliah penginderaan jauh khususnya aplikasi penginderaan jauh pada wilayah pesisir dan laut.

\section{Metode}

\subsection{Waktu dan Lokasi Penelitian}

Penelitian dilaksanakan pada bulan Januari 2019 - Februari 2019 di Perairan Pasir Putih Kabupaten Situbondo, Jawa Timur (Gambar 1). Area penelitian meliputi 4 wilayah yaitu Watu Lawang, Karang Mayit, Teluk Pelita, dan Karang Pon Pon. Pengolahan data citra satelit dilakukan di Laboratorium Eksplorasi Sumberdaya Kelautan dan Perikanan FPIK Universitas Brawijaya, Malang. Pengambilan data lapangan terumbu karang dilakukan pada tanggal 5-12 Februari 2019.

\subsection{Data Citra Satelit}

Citra satelit yang digunakan adalah Sentinel-2A yang diakuisisi pada tanggal 06 Januari 2019 didapatkan dengan mengunduh tanpa berbayar di $h t t p s: / / s c i h u b . c o p e r n i c u s . e u$. Sentinel2A menghasilkan citra optik multispektral yang mempunyai 13 band, dibagi ke beberapa spektrum visible, near infrared, shortwave infrared. Resolusi spasial dari satelit Sentinel-2A adalah 4 band dengan resolusi $10 \mathrm{~m}, 6$ band dengan resolusi $20 \mathrm{~m}$ dan 3 band lainnya dengan resolusi $60 \mathrm{~m}$. Sedangkan luas sapuan dari satelit Sentinel-2A adalah $290 \mathrm{~km}$ (European Space Agency, 2015). 


\section{Jurnal Pendidikan Geografi:}

Kajian, Teori, dan Praktik dalam Bidang Pendidikan dan Ilmu Geografi

27(1), 2022, 73-87

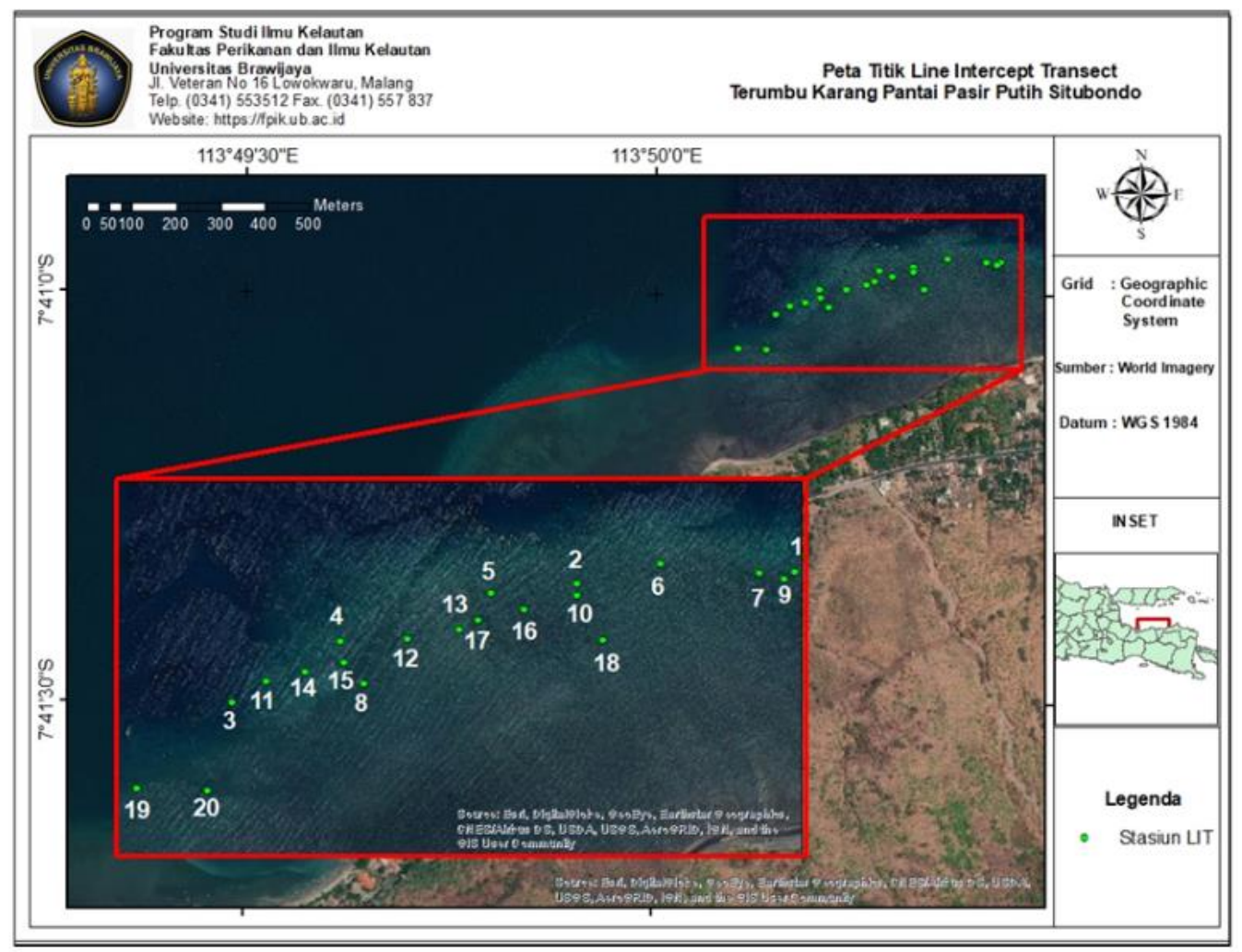

Gambar 1. Lokasi Survei Pengambilan Data Terumbu Karang

\subsection{Diagram Alir Penelitian}

Penelitian ini dimulai dengan mengunduh dan mengolah citra satelit untuk mendapatkan peta sebaran terumbu karang, selanjutnya dilakukan survei lapang untuk validasi dan identifikasi kondisi terumbu karang. Selanjutnya pre-processing data yang pertama pada Citra Sentinel-2 untuk ekstraksi informasi terumbu karang meliputi koreksi radiometrik. Koreksi ini dilakukan dengan bantuan software SNAP dan QGIS 2.18 dengan menggunakan tools plug-in Semi-Automatic Classification (SCP). Langkah selanjutnya adalah Pemotongan citra atau biasa disebut cropping. Kemudian citra hasil pemotongan dilakukan transformasi untuk penajaman citra. Proses penajaman citra dilakukan untuk memperbaiki kualitas citra sehingga mudah untuk membedakan objek yang terekam oleh citra. Metode untuk meningkatkan ketelitian informasi di bawah permukaan perairan dangkal menggunakan Depth Invariant Index (DII) atau metode koreksi kolom air di permukaan perairan dangkal (Lyzenga, 1978, 1981). Pengaruh kolom air pada citra dapat dikurangi melalui koreksi kolom air yang dikembangkan oleh (Lyzenga, 1981). Diagram alir penelitian disajikan pada Gambar 2 dan algoritma yang digunakan adalah Algoritma Lyzenga seperti pada kajian (Green, 2018).

$$
\begin{aligned}
& \mathrm{Y}=\ln (L i)-\left[\left(\frac{k i}{k j}\right) \ln (L i)\right] \\
& \frac{k i}{k j}=a+\sqrt{\left(a^{2}+1\right.} \\
& a=\frac{\sigma i i-\sigma j j}{2 \sigma i j}
\end{aligned}
$$


Jurnal Pendidikan Geografi:

Kajian, Teori, dan Praktik dalam Bidang Pendidikan dan Ilmu Geografi

27(1), 2022, 73-87

Keterangan:

Li \& Lj = nilai digital pada band ke-i \& band ke-j

$\mathrm{Ki} / \mathrm{Kj} \quad=$ rasio koefisien atenuasi pada pasangan band $\mathrm{i}$ dan $\mathrm{j}$

$\sigma$ ii $\quad=$ varian band $\mathrm{i}$

$\sigma \mathrm{jj} \quad=$ varian band $\mathrm{j}$

$\sigma \mathrm{ij} \quad=$ kovarian band $\mathrm{ij}$

Setelah proses transformasi Lyzenga, dilakukan klasifikasi ISOCLASS Unsupervised classification dimana dilakukan dengan software ErMapper 7.1 dengan metode pengklasifikasian objek. Hasil dari Isoclass Unsupervised diberi warna kemudian dilakukan proses selanjutnya yaitu reclass dan editing.

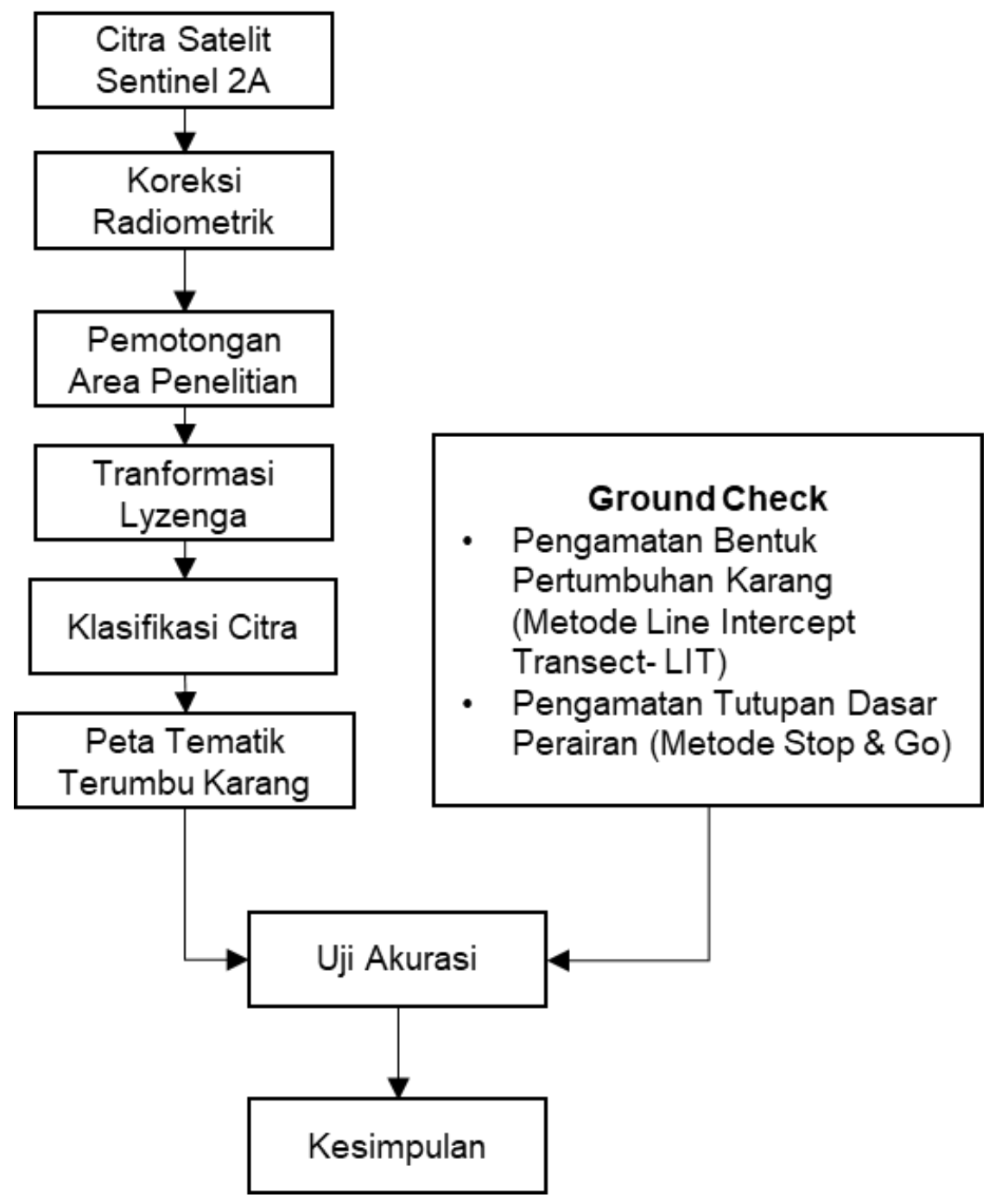

Gambar 2. Diagram Alir Penelitian 


\subsection{Survei Terumbu Karang}

\subsubsection{Ground check untuk analisis akurasi citra}

Proses ground check dilakukan dengan cara mengambil masing-masing 30 titik dari setiap parameter yang telah diolah sebelumnya. Penentuan titik dilakukan dengan cara random sampling menggunakan metode stop and go mengikuti Perka BIG No 8 Tahun 2014 tentang Pedoman Teknis Pengumpulan dan Pengolahan Data Geospasial Habitat Dasar Perairan Laut Dangkal (Badan Informasi Geospasial, 2018). Titik validasi terumbu karang berdasarkan citra Sentinel-2 di Pantai Pasir Putih Situbondo sejumlah 90 titik yang terdiri atas 30 titik validasi merupakan karang mati, 30 karang hidup dan 30 lainnya merupakan pasir (Gambar 3).

\subsubsection{Survei Keanekaragaman Karang}

Metode survei yang digunakan adalah metode Line Intercept Transect (LIT) (English, Wilkinson, \& Baker, 1997). Tingkat ketelitian keanekaragaman karang yang digunakan pada penelitian ini berada pada tingkat bentuk pertumbuhan (lifeform) yaitu Acropora Branching (ACB), Acropora Tabulate (ACT), Acropora Encrusting (ACE), Acropora Submassive (ACS), Acropora Digitate (ACD), Non-Acropora Branching Coral (CB), Non-Acropora Encrusting (CE), Coral Foliose (CF), Coral Massive (CM), Coral Submassive (CS), Coral Mushroom (CMR), Coral Millepora (CME), Coral Heliopora (CHL), Sand (SD), Rubble (RB), dan Rock (RCK). Survei dilakukan dengan membentangkan tali pengukur atau meteran pada hamparan terumbu karang sepanjang $20 \mathrm{~m}$ dengan posisi bentangan sejajar garis pantai atau mengikuti alur pinggiran karang pada kedalaman $5 \mathrm{~m}$ dengan total 20 transek.

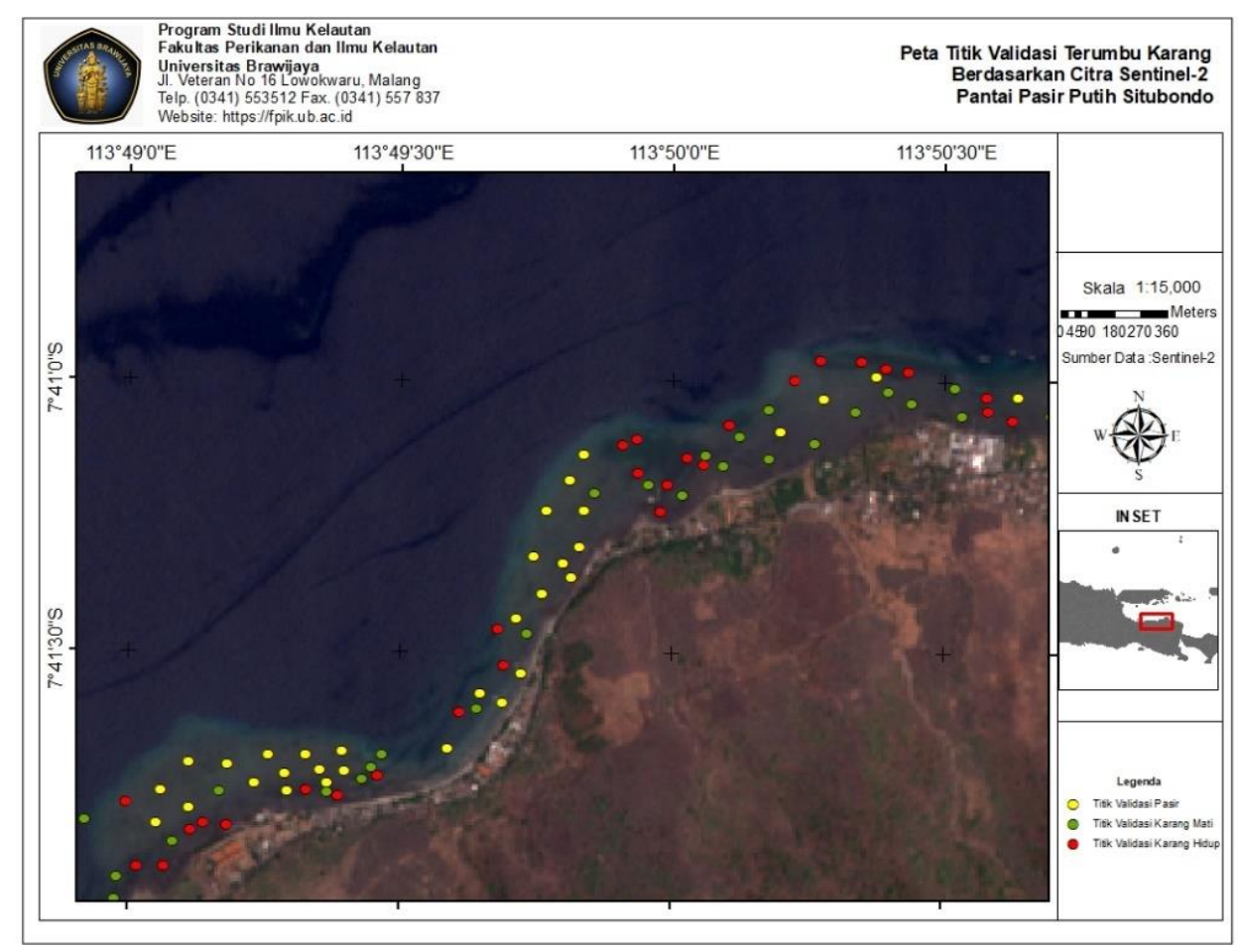

Gambar 3. Titik Pengamatan Tutupan Dasar Perairan untuk Analisis Akurasi Hasil Interpretasi Citra 


\section{Jurnal Pendidikan Geografi:}

Kajian, Teori, dan Praktik dalam Bidang Pendidikan dan Ilmu Geografi

27(1), 2022, 73-87

\subsection{Analisis Akurasi Citra}

Perhitungan analisis ketelitian hasil interpretasi citra dilakukan dengan metode tabel matrik kesalahan atau sering disebut dengan confusion matrix (Amrillah, Adi, \& Kurniawan, 2019; Congalton \& Green, 2019; Tempfli et al., 2009). Nilai akurasi minimal yang dapat diterima untuk pemetaan habitat dasar perairan laut dangkal berdasarkan pada SNI 7716:2011 adalah sebesar $\geq 60 \%$ (BSN, 2011).

\section{Hasil dan Pembahasan}

\subsection{Klasifikasi Citra Satelit untuk Pemetaan Terumbu karang}

Klasifikasi yang digunakan dalam penelitian yang berlokasi di Pantai Pasir Putih Situbondo adalah dengan menggunakan klasifikasi tak terbimbing (unsupervised classification) terhadap citra hasil penerapan Algoritma Lyzenga untuk mengetahui tutupan dasar perairan wilayah yang diteliti, kemudian dilanjutkan dengan klasifikasi supervised. Pada penelitian ini, klasifikasi citra ditentukan dengan jumlah kelas awal sebanyak 50, kemudian dari 50 kelas tersebut diklasifikasikan dengan metode unsupervised classification menjadi 3 kelas berdasarkan perbedaan warna. Hasil klasifikasi sebaran terumbu karang terbagi menjadi 3 kelas yaitu karang hidup, karang mati dan pasir (Gambar 3). Selanjutnya hasil tersebut juga diukur luasnya untuk masing masing- kelas. Luasan dari tiga kelas disajikan pada Tabel 1.

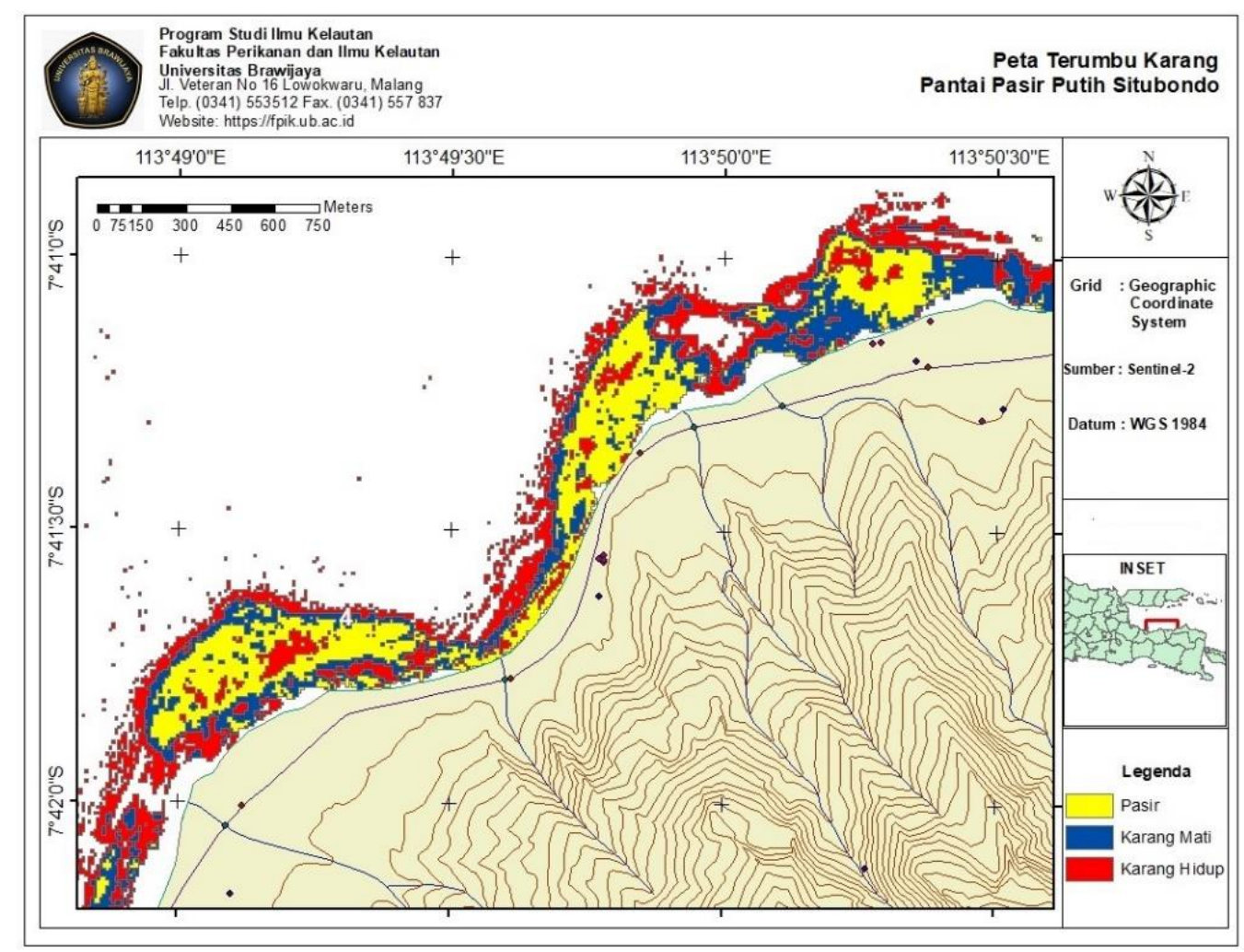

Gambar 4. Peta Sebaran Terumbu Karang di Pasir Putih, Probolinggo 
Jurnal Pendidikan Geografi:

Kajian, Teori, dan Praktik dalam Bidang Pendidikan dan Ilmu Geografi

27(1), 2022, 73-87

Tabel 1. Hasil Klasifikasi Sebaran Terumbu Karang Pasir Putih, Situbondo

\begin{tabular}{lll}
\hline No & Jenis Substrat & Luas (Ha) \\
\hline 1 & Karang Hidup & 32,860 \\
2 & Karang Mati & 31,690 \\
3 & Pasir & 42,670 \\
\hline Jumlah & 107,220 \\
\hline
\end{tabular}

Tabel 2. Evaluasi Akurasi Peta Terumbu Karang Hasil Interpretasi

\begin{tabular}{lllll}
\hline \multirow{2}{*}{ Citra Hasil } & \multicolumn{5}{c}{ Survei } \\
\cline { 2 - 5 } & Karang Hidup & Karang Mati & Pasir & Total \\
\hline Karang Hidup & 21 & 1 & 8 & 30 \\
Karang Mati & 2 & 18 & 8 & 28 \\
Pasir & 3 & 3 & 26 & 32 \\
\hline Total & 26 & 22 & 42 & $(21+18+26) / 90$ \\
\hline
\end{tabular}

\subsection{Analisis Akurasi Peta Sebaran Terumbu Karang}

Akurasi total dari peta sebaran terumbu karang yang dihasilkan adalah 72,2\% (Tabel 2). Nilai akurasi tersebut tergolong berada pada kategori baik yaitu berkisar lebih dari 70\% dan telah sesuai dengan SNI 7716:2011 yang mensyaratkan akurasi minimal untuk pemetaan terumbu karang dengan citra resolusi menengah adalah lebih dari $60 \%$. Penelitian ini menghasilkan 3 kelas klasifikasi, yaitu karang hidup, karang mati dan pasir. Karang hidup ada pada 21 titik atau $70 \%$ dari total 30 titik survei lapang hasil interpretasi citra. Sedangkan dari keseluruhan peta dapat dilihat klasifikasi pasir lebih banyak ditemukan dibandingkan karang hidup dan karang mati dengan akurasi sebesar 81\% (26 titik sesuai dari 30 titik survei). Penghitungan akurasi total mengikuti rumus berikut:

$$
\begin{aligned}
\text { Akurasi Total } & =\frac{\sum \text { sampel yang benar }}{\sum \text { seluruh sampel }} \times 100 \% \\
& =\frac{21+18+26}{90} \times 100 \% \\
& =72,2 \%
\end{aligned}
$$

Penelitian ini menghasilkan nilai akurasi yang masuk dalam range SNI 7716:2011, lebih dari 60\%. Akurasi yang relatif tinggi pada penelitian ini, salah satunya disebabkan oleh rendahnya tutupan awan (kurang dari 20\%). Rendahnya akurasi peta dan kualitas hasil akhir citra dapat disebabkan oleh tutupan awan (Putro \& Handayani, 2015). Selain itu, akurasi peta juga dipengaruhi oleh jumlah kelas, metode pengambilan, dan jumlah titik ground truth sampel penguji (Sugara, Siregar, \& Agus, 2020).

\subsection{Keanekaragaman dan Kondisi Terumbu Karang}

Pada penelitian keanekaragaman karang diidentifikasi sampai dengan tingkat bentuk pertumbuhan karang (life form). Kategori lifeform karang yang paling banyak ditemukan mulai dari Stasiun 1 sampai dengan Stasiun 20 yaitu Coral Massive, Acropora Branching dan juga Acropora Tabulate, dimana hampir di setiap stasiun ditemukan life form dari Coral Massive dan Acropora Branching. Sedangkan lifeform yang paling jarang ditemui yaitu jenis Acropora Submassive dan Coral Mushroom. 


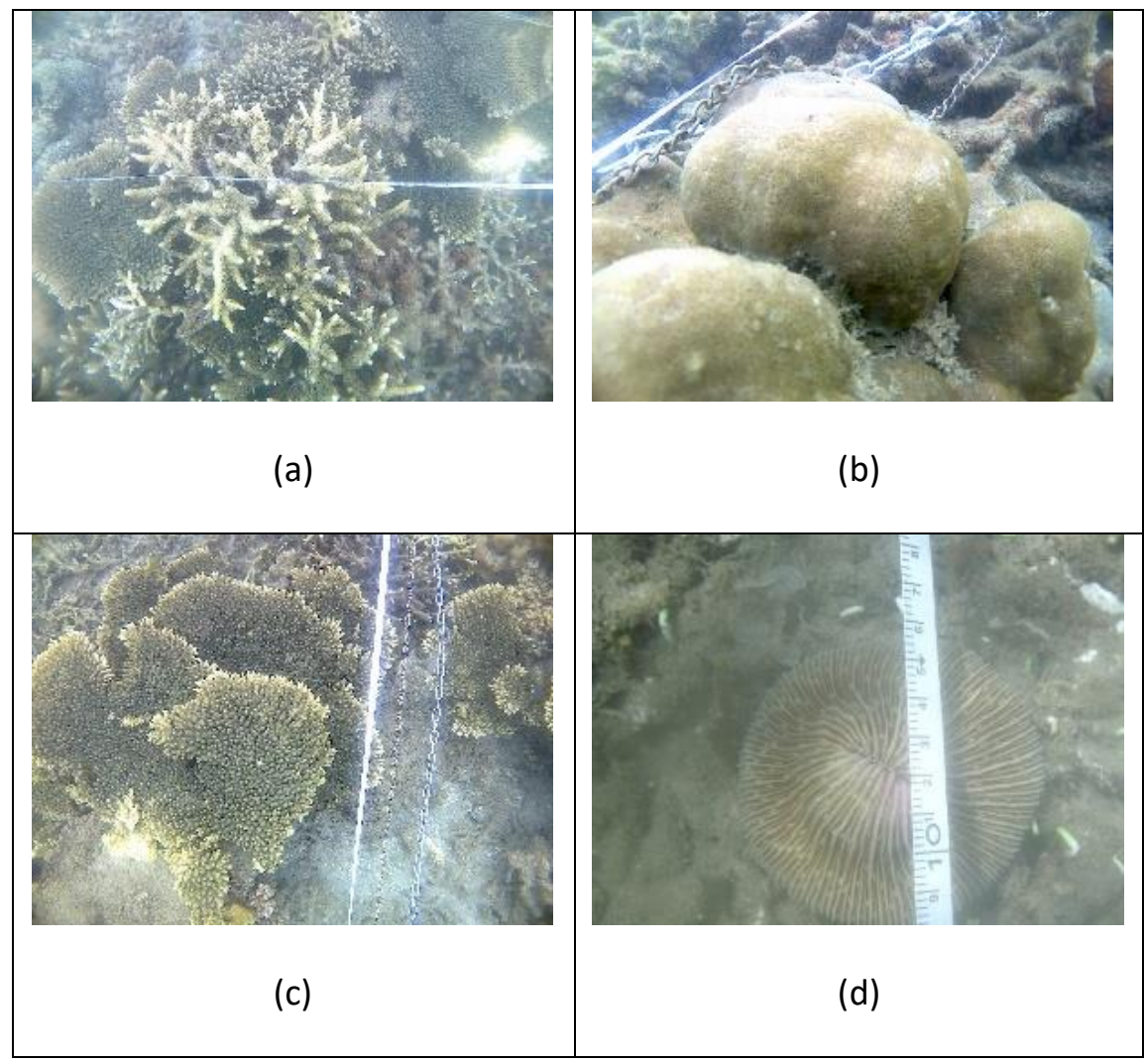

\section{Gambar 5. Life Form Karang yang Ditemukan di Pasir Putih, Situbondo, (a) Acropora Branching, (b) Coral Massive, (c) Acropora Tabulate, dan (d) Coral Mushroom}

Persentase terumbu karang di transek 1 sampai transek 20 dapat dilihat pada Tabel 3. Berdasarkan tabel 3, 13 transek terumbu karang di pantai pasir putih umumnya masuk kategori rusak buruk (Menteri Negara Lingkungan Hidup, 2001). Tujuh transek tergolong rusak sedang, dan tidak terdapat karang pada kategori sangat baik dan baik. Tutupan terumbu karang tertinggi dengan nilai $41 \%$ di Titik 12 dan nilai terendah di Titik 17 dengan nilai 4\%. Sehingga dapat diketahui hasil dari pengambilan data terumbu karang dapat dikategorikan karang buruk karena persentase tutupan terumbu karang sekitar 0-40\% saja.

Tutupan pasir tertinggi terdapat di titik 8 dengan nilai $65,5 \%$ dan nilai terendah di titik 10 dengan nilai $0 \%$. Nilai pecahan karang tertinggi di titik 5 dengan liat 74,25\% kemudian nilai terendah di titik 7 yaitu 0 atau tidak ada pecahan karang. Karang mati memiliki nilai tertinggi di titik 17 dengan nilai 73,5\%, sedangkan nilai karang mati terendah di titik 3, titik 11 dan titik 19 dengan nilai 0\%. Secara umum kondisi ekosistem terumbu karang di Perairan Pasir Putih dalam kondisi 'rusak sekali/kritis' hingga 'rusak'. Kondisi ekosistem terumbu karang dapat digambarkan melalui persentase tutupan karang hidup yaitu proporsi koloni karang keras dalam keadaan hidup yang menyusun ekosistem terumbu karang dibandingkan dengan keseluruhan ekosistem penyusun terumbu karang. Hasil penelitian lainnya juga menyatakan sudah terjadi perubahan kondisi Terumbu Karang di Pasir Putih dapat dilihat pada Tabel 4. 
Jurnal Pendidikan Geografi:

Kajian, Teori, dan Praktik dalam Bidang Pendidikan dan Ilmu Geografi

27(1), 2022, 73-87

Tabel 4. Perkembangan Kondisi Terumbu Karang di Pasir Putih

\begin{tabular}{|c|c|c|c|c|}
\hline Sumber & $\begin{array}{l}\text { Lokasi dan Jumlah } \\
\text { Sampel }\end{array}$ & $\begin{array}{l}\text { Jumlah } \\
\text { Transek }\end{array}$ & Metode & $\begin{array}{l}\text { Kondisi } \\
\text { Karang }\end{array}$ \\
\hline Penelitian Ini & $\begin{array}{l}\text { Watu Lawang, Karang } \\
\text { mayit, Teluk Pelita }\end{array}$ & 20 & $\begin{array}{l}\text { LIT } \\
\text { (Line } \\
\text { Intercept } \\
\text { Transect) }\end{array}$ & $\begin{array}{l}4-41 \% \\
\text { (Rusak- } \\
\text { Sedang) }\end{array}$ \\
\hline $\begin{array}{l}\text { Hapsari, Pratiwi, } \\
\text { Romadhon, dan } \\
\text { Kisnarti (2017) }\end{array}$ & $\begin{array}{l}\text { Watu Lawang, Karang } \\
\text { mayit }\end{array}$ & 2 & $\begin{array}{l}\text { LIT } \\
\text { (Line } \\
\text { Intercept } \\
\text { Transect) }\end{array}$ & $\begin{array}{l}20-28 \% \\
\text { (Kritis / } \\
\text { rusak) }\end{array}$ \\
\hline Saputra (2016) & $\begin{array}{l}\text { Watu Lawang, Karang } \\
\text { Mayit, Teluk Pelita, } \\
\text { Karang Pon Pon }\end{array}$ & 9 & $\begin{array}{l}\text { UPT } \\
\text { (Underwater } \\
\text { Photo } \\
\text { Transect) }\end{array}$ & $\begin{array}{l}27-32 \% \\
\text { (Kritis / } \\
\text { rusak) }\end{array}$ \\
\hline $\begin{array}{l}\text { Luthfi, Naradiarga, } \\
\text { dan Jauhari (2014) }\end{array}$ & $\begin{array}{l}\text { Watu Lawang, Karang } \\
\text { Pon Pon }\end{array}$ & 2 & $\begin{array}{l}\text { LIT } \\
\text { (Line } \\
\text { Intercept } \\
\text { Transect) }\end{array}$ & $\begin{array}{l}23-49 \% \\
\text { (Rusak- } \\
\text { Sedang) }\end{array}$ \\
\hline Hayuni (2007) & $\begin{array}{l}\text { Batu Lawang, Teluk } \\
\text { Pelita, Karang Mayit, dan } \\
\text { Kembang Sambi }\end{array}$ & 4 & $\begin{array}{l}\text { LIT } \\
\text { (Line } \\
\text { Intercept } \\
\text { Transect) }\end{array}$ & $\begin{array}{l}22,49- \\
50,61 \\
\text { (Rusak- } \\
\text { Sedang) }\end{array}$ \\
\hline
\end{tabular}

Kawasan terumbu karang yang digunakan untuk kegiatan wisata akan mengalami tekanan dan mengarah pada kerusakan (Akhmad et al., 2018). Hal tersebut juga terjadi pada terumbu karang di Pantai Pasir Putih Situbondo. Pantai Pasir Putih telah dicanangkan sebagai 82kawasan konservasi sesuai dengan Peraturan Bupati Situbondo Nomor 19 Tahun 2012 tentang Pencadangan Kawasan Terumbu Karang Pasir Putih sebagai Kawasan Konservasi Perairan Daerah Kabupaten Situbondo (Pemerintah Daerah Kabupaten Situbondo, 2012). Namun, berdasarkan data pada Tabel 4, kondisi karang dari tahun ke tahun tidak semakin membaik. Salah satu kegiatan wisata yang berpotensi untuk mengancam keberadaan terumbu karang adalah snorkeling. Kegiatan ini menjadi salah satu dari berbagai ancaman yang terjadi pada terumbu karang apabila tidak dilakukan dengan benar (Akhmad et al., 2018). Kegiatan wisata bahari dapat menyebabkan menurunnya kualitas lingkungan, seperti tidak tertatanya lingkungan akibat banyaknya pembangunan di kawasan pariwisata (Khrisnamurti, Utami, \& Darmawan, 2017). Selain karena snorkelling dan aktivitas wisata pantai lainnya, kerusakan karang dapat juga diakibatkan oleh kegiatan pariwisata penyelaman. Para penyelam membutuhkan kapal untuk sampai di titik lokasi dive spot. Jangkar dari kapal tersebut dapat merusak karang-karang yang ada di Pantai Pasir Putih.

Aktivitas pariwisata tersebut berpengaruh terhadap kondisi terumbu karang. Selain itu, faktor yang turut mempengaruhi kondisi terumbu karang adalah sedimentasi (Adriman, Purbayanto, Budiharso, \& Damar, 2013; Erftemeijer, Riegl, Hoeksema, \& Todd, 2012). Sedimentasi Pantai Pasir Putih terjadi karena banyaknya sedimen yang terbawa oleh air sungai dan banjir. Berdasarkan pemberitaan dari media elektronik nasional, pada tahun 2017 terjadi 2 kali banjir bandang di wilayah jalan raya Pasir Putih Situbondo (Dasuqi, 2017; Husdinariyanto, 2017). Sedimen yang terbawa banjir tersebut menuju ke laut sehingga menutupi permukaan terumbu karang dan menyebabkan kematian sebagian polip karang karena kekurangan cahaya matahari untuk respirasi (Erftemeijer et al., 2012; Supriharyono, 
Jurnal Pendidikan Geografi:

Kajian, Teori, dan Praktik dalam Bidang Pendidikan dan Ilmu Geografi

27(1), 2022, 73-87

2000). Koloni karang yang paling banyak ditemukan di Pasir Putih yaitu Porites yang berbentuk massive dan karang Acropora bercabang yang rentan terhadap sedimentasi. Hal ini sesuai dengan penelitian yang dilakukan oleh Barus, Prartono, dan Soedarma (2018); Luthfi dan Yamindago (2008); Mellani, Hendrawan, dan Karim (2019) yang menyatakan bahwa koloni karang Porites yang berbentuk massive dan karang yang bercabang lebih mudah terkena kerusakan akibat sedimentasi. Kondisi terumbu yang rentan ini membutuhkan perbaikan atau rehabilitasi yang lebih intensif.

Rehabilitasi yang intensif telah dilaksanakan di perairan Pantai Pasir Putih yang berupa penempatan terumbu buatan (Akhwady, Tamtomo, \& Luthfi, 2018; Saptarini, 2010; Yanuar \& Aunurohim, 2015), dan transplantasi karang (Dinas Penerangan Korps Marinir, 2015). Rehabilitasi terumbu karang secara umum dapat memperbaiki kondisi terumbu karang. Beberapa kegiatan rehabilitasi telah berhasil memperbaiki kondisi terumbu karang. Contohnya rehabilitasi yang dilakukan oleh Subhan, Madduppa, Arafat, dan Soedharma (2014), yaitu transplantasi karang dengan penggunaan beton sebagai substrat penempelan; penelitian Taufina, Faisal, dan Lova (2018) dengan kombinasi kegiatan pembuatan terumbu buatan dan transplantasi karang, dan penelitian Ampou, Widagti, Nugroho, dan Sangadji (2020) menggunakan biorock sebagai substrat penempelan karang donor.

\section{Simpulan}

Luas area karang hidup di perairan Pantai Pasir Putih seluas 32.860 Ha, karang mati 31.690 Ha dan pasir 42.670 Ha. Tingkat akurasi peta yang dihasilkan sebesar 72,2\% yang termasuk dalam kategori baik yaitu lebih dari 70\%. Tutupan karang hidup di Pantai Pasir Putih antara 4\%-41\% sehingga dapat dikategorikan dalam kondisi rusak buruk-rusak sedang dengan jenis lifeform paling banyak ditemukan adalah Coral Massive dan Acropora Branching. Selain itu penelitian ini dapat dijadikan contoh ataupun studi kasus dalam pembelajaran pada mata kuliah penginderaan jauh khususnya aplikasi penginderaan jauh pada wilayah pesisir dan laut.

\section{Ucapan Terimakasih}

Penelitian ini dibiayai oleh Marine Resources Exploration and Management Research Group (RG-MEXMA) FPIK-Universitas Brawijaya melalui Hibah Penelitian tahun 2019. Terimakasih disampaikan kepada pengelola kawasan wisata bahari dan Pokmaswas Pasir Putih atas bantuan yang telah diberikan dalam survei dan pengambilan data.

\section{Daftar Rujukan}

Adriman, A., Purbayanto, A., Budiharso, S., \& Damar, A. (2013). Pengaruh sedimentasi terhadap terumbu karang di kawasan konservasi laut daerah Bintan Timur Kepulauan Riau. Berkala Perikanan Terubuk, 41(1), 90-101.

Akhmad, D. S., Purnomo, P. W., \& Supriharyono, S. (2018). Potensi kerusakan terumbu karang pada kegiatan wisata snorkeling di destinasi wisata Taman Nasional Karimunjawa. Jurnal Ilmu dan Teknologi Kelautan Tropis, 10(2), 419-429. https://doi.org/https://doi.org/10.29244/jitkt.v10i2.21495

Akhwady, R., Tamtomo, P. C., \& Luthfi, O. M. (2018). Used evaluation of stone ash and clamshell as concrete material of artificial reef at Pasir Putih Beach, Situbondo-Indonesia. International Journal of Basic \& Applied Sciences IJBAS-IJENS, 8(2), 1-7.

Ampou, E. E., Widagti, N., Nugroho, S. C., \& Sangadji, I. M. (2020). Status terumbu karang dan ikan karang di Gili Matra, Nusa Tenggara Barat. Ecotrophic, 14(1), 14-27.

Amrillah, K., Adi, W., \& Kurniawan, K. (2019). Pemetaan sebaran terumbu karang di perairan Pulau Kelapan, Kabupaten Bangka Selatan berdasarkan data satelit Sentinel 2A. Journal of Tropical Marine Science, 2(2), 59-70. 
Jurnal Pendidikan Geografi:

Kajian, Teori, dan Praktik dalam Bidang Pendidikan dan Ilmu Geografi

$$
\text { 27(1), 2022, 73-87 }
$$

Andrefouet, S., \& Guzman, H. M. (2005). Coral reef distribution, status and geomorphology-biodiversity relationship in Kuna Yala (San Blas) archipelago, Caribbean Panama. Coral Reefs, 24(1), 31-42.

Badan Informasi Geospasial. (2018). DEMNAS seamless Digital Elevation Model (DEM) dan Batimetri Nasional. Badan Informasi Geospasial. http://tides.big.go.id/DEMNAS/Jawa.php

Barus, B. S., Prartono, T., \& Soedarma, D. (2018). Keterkaitan sedimentasi dengan persen tutupan terumbu karang di perairan Teluk Lampung. Jurnal Ilmu dan Teknologi Kelautan Tropis, 10(1), 49-57.

BSN. (2011). SNI 7716:2011 Pemetaan habitat perairan laut dangkal-Bagian 1: Pemetaan terumbu karang dan padang lamun. bsn.go.id. https://pesta.bsn.go.id/produk/detail/8757-sni77162011

Cahyani, W. S., Setyobudiandi, I., \& Affandy, R. (2018). Kondisi dan status keberlanjutan ekosistem terumbu karang di kawasan konservasi perairan Pulo Pasi Gusung, Selayar. Jurnal Ilmu dan Teknologi Kelautan Tropis, 10(1), 153-166. https://doi.org/10.29244/jitkt.v10i1.21672

Congalton, R. G., \& Green, K. (2019). Assessing the accuracy of remotely sensed data: Principles and practices. CRC press.

Dasuqi, G. (2017). Jalur Pantura Situbondo sempat lumpuh tergenang banjir. news.detik.com. https://news.detik.com/berita-jawa-timur/d-3396494/jalur-pantura-situbondo-sempat-lumpuh-tergenangbanjir

Dinas Penerangan Korps Marinir. (2015). Marinir tanam terumbu karang di Pantai Pasir Putih Situbondo. Kompasiana. https://www.kompasiana.com/dispenkormar/557e688af87a61fe0557359f/marinirtanam-terumbu-karang-di-pantai-pasir-putih-situbondo

Edrus, I. N., \& Hadi, T. A. (2020). Struktur komunitas ikan karang di perairan pesisir Kendari Sulawesi Tenggara. Jurnal Penelitian Perikanan Indonesia, 26(2), 59-73.

English, S., Wilkinson, C., \& Baker, V. (1997). Survey manual for tropical marine resources.

Erftemeijer, P. L. A., Riegl, B., Hoeksema, B. W., \& Todd, P. A. (2012). Environmental impacts of dredging and other sediment disturbances on corals: A review. Marine Pollution Bulletin, 64(9), 1737-1765.

European Space Agency. (2015). Sentinel-2 user handbook. In Sentinel 2 Document Library. ESA.

Green, L. (2018). Migration, urbanization, and national development in Nigeria. In Modern Migrations in Western Africa (pp. 281-304). Routledge.

Hadi, T. A., Prayudha, B., Hafizt, M., \& Budiyanto, A. (2018). Status terumbu karang Indonesia 2018. Pusat Penelitian Oseanografi LIPI.

Hamylton, S. M. (2017). Mapping coral reef environments: A review of historical methods, recent advances and future opportunities. Progress in Physical Geography, 41(6), 803-833. https://doi.org/10.1177/0309133317744998

Hapsari, R. A., Pratiwi, M. E., Romadhon, R. P., \& Kisnarti, E. A. (2017). Kondisi terumbu karang di perairan Situbondo. Prosiding Seminar Nasional Kelautan dan Perikanan III, 55-63.

Hayuni, D. S. B. (2007). Potensi ekosistem terumbu karang untuk pengembangan wisata bahari Pasir Putih Kabupaten Situbondo. Universitas Gadjah Mada.

Hedley, J. D., Roelfsema, C. M., Chollett, I., Harborne, A. R., Heron, S. F., Weeks, S. J., ... Mumby, P. J. (2016). Remote sensing of coral reefs for monitoring and management: A review. Remote Sensing, 8(2). https://doi.org/10.3390/rs8020118

Husdinariyanto, N. (2017). Banjir Situbondo juga rusak fasilitas wisata Pasir Putih. jatim.antaranews.com. https://jatim.antaranews.com/berita/191034/banjir-situbondo-juga-rusak-fasilitas-wisata-pasirputih-video

Jubaedah, I., \& Anas, P. (2019). Dampak pariwisata bahari terhadap ekosistem terumbu karang di perairan Nusa Penida, Bali. Jurnal Penyuluhan Perikanan dan Kelautan, 13(1), 59-75. https://doi.org/10.33378/jppik.v13i1.124

Khrisnamurti, K., Utami, H., \& Darmawan, R. (2017). Dampak pariwisata terhadap lingkungan di Pulau Tidung Kepulauan Seribu. Kajian, 21(3), 257-273.

Khusnah, A., Retnaningdyah, C., \& Kurniawan, N. (2019). Community structure of coral reef at Pasir Putih Beach in Situbondo East Java, Indonesia. Journal of Indonesian Tourism and Development Studies, 7(1), 32-38. https://doi.org/10.21776/ub.jitode.2019.07.01.05 


\section{Jurnal Pendidikan Geografi:}

\section{Kajian, Teori, dan Praktik dalam Bidang Pendidikan dan Ilmu Geografi}

$$
\text { 27(1), 2022, 73-87 }
$$

Krieger, J. R., \& Chadwick, N. E. (2013). Recreational diving impacts and the use of pre-dive briefings as a management strategy on Florida coral reefs. Journal of Coastal Conservation, 17(1), 179-189. https://doi.org/10.1007/s11852-012-0229-9

Luthfi, O. M., Naradiarga, L., \& Jauhari, A. (2014). Gangguan kesehatan karang di wilayah perairan cagar alam Sempu, Kabupaten Malang, Jawa Timur compromised health on coral at Sempu Nature Reserve Malang Regency East Java. Prosiding PIT XI ISOI.

Luthfi, O. M., \& Yamindago, A. (2008). Telaah struktur komunitas terumbu karang sebagai studi awal program rehabilitasi terumbu karang di perairan Pasir Putih Situbondo. Fakultas Perikanan dan Ilmu Kelautan, Universitas Brawijaya, Malang.

Lyzenga, D. R. (1978). Passive remote sensing techniques for mapping water depth and bottom features. Applied Optics, 17(3), 379-383.

Lyzenga, D. R. (1981). Remote sensing of bottom reflectance and water attenuation parameters in shallow water using aircraft and landsat data. International Journal of Remote Sensing, 2(1), 71-82.

Mellani, N. P. F., Hendrawan, I. W., \& Karim, W. (2019). Kondisi kesehatan karang genus porites di perairan Jemeluk dan Penuktukan-Bali. Journal of Marine and Aquatic Sciences, 5(1), 29-35.

Menteri Negara Lingkungan Hidup. (2001). Keputusan Menteri Negara Lingkungan Hidup No. 4 tahun 2001 tentang kriteria baku kerusakan terumbu karang. Jakarta.

Moll, H. (1986). The coral community structure on the reefs visited during the Snellius II Expedition in eastern Indonesia. Zoologische Mededelingen, 60(1), 1-25.

Muthahharah, A., \& Adiwibowo, S. (2017). Dampak obyek wisata Pantai Pasir Putih Situbondo terhadap peluang bekerja dan berusaha. Jurnal Sains Komunikasi dan Pengembangan Masyarakat [JSKPM], 1(2), 157-166.

Nurhaliza, S., Muhlis, M., Bachtiar, I., \& Santoso, D. (2019). Struktur komunitas karang keras (scleractinia) di zona intertidal Pantai Mandalika Lombok Tengah. Jurnal Biologi Tropis, 19(2), 302-308.

Pemerintah Daerah Kabupaten Situbondo. (2012). Peraturan Bupati Situbondo nomor 19 tahun 2012 tentang pencadangan kawasan terumbu karang Pasir Putih sebagai kawasan konservasi perairan daerah Kabupaten Situbondo. Situbondo.

Putro, F. W., \& Handayani, T. (2015). Penghilangan awan pada citra satelit dengan citra multi temporal dan inpainting berbasis self organizing map. Technology Dynamic, 7(1), 5-21.

Saptarini, D. (2010). Evaluasi terumbu buatan dalam peningkatan kualitas lingkungan Pantai Pasir Putih Situbondo.

Saputra, S. A. (2016). Keanekaragaman dan penutupan terumbu karang di Pantai Pasir Putih Situbondo, Jawa Timur. UAJY.

Subhan, B., Madduppa, H., Arafat, D., \& Soedharma, D. (2014). Bisakah Transplantasi karang perbaiki ekosistem terumbu karang?. Risalah Kebijakan Pertanian dan Lingkungan Rumusan Kajian Strategis Bidang Pertanian dan Lingkungan, 1(3), 159-164.

Sugara, A., Siregar, V. P., \& Agus, S. B. (2020). Klasifikasi habitat bentik perairan dangkal dari citra worldview2 menggunakan data in-situ dan drone. Jurnal Ilmu dan Teknologi Kelautan Tropis, 12(1), 135-150.

Supriharyono, S. (2000). Pengelolaan ekosistem terumbu karang. Jakarta: Djambatan.

Taufina, T., Faisal, F., \& Lova, S. M. (2018). Rehabilitasi terumbu karang melalui kolaborasi terumbu buatan dan transplantasi karang di Kecamatan Bungus Teluk Kabung Kota Padang: Kajian deskriptif pelaksanaan corporate social responsibility (Csr) Pt. Pertamina (Persero) marketing operation region (Mo). Jurnal Pengabdian Kepada Masyarakat, 24(2), 730-739.

Tempfli, K., Huurneman, G., Bakker, W., Janssen, L. L. F., Feringa, W. F., Gieske, A. S. M., ... Kerle, N. (2009). Principles of remote sensing: An introductory textbook. International Institute for Geo-Information Science and Earth Observation.

Toyoshima, J., \& Nadaoka, K. (2015). Importance of environmental briefing and buoyancy control on reducing negative impacts of SCUBA diving on coral reefs. Ocean and Coastal Management, 116, 20-26. https://doi.org/10.1016/j.ocecoaman.2015.06.018

Veron, J. E. N. (2002). New species described in corals of the world (Vol. 11). Citeseer. 
Jurnal Pendidikan Geografi:

Kajian, Teori, dan Praktik dalam Bidang Pendidikan dan Ilmu Geografi

27(1), 2022, 73-87

Yanuar, A., \& Aunurohim, A. (2015). Komunitas ikan karang pada tiga model terumbu buatan (artificial reef) di perairan Pasir Putih Situbondo, Jawa Timur. Jurnal Sains dan Seni ITS, 4(1), E19-E24. 
Jurnal Pendidikan Geografi:

Kajian, Teori, dan Praktik dalam Bidang Pendidikan dan Ilmu Geografi

27(1), 2022, 73-87

Tabel 3. Jenis dan Persentase Tutupan Terumbu Karang di Perairan Pasir Putih, Situbondo

\begin{tabular}{|c|c|c|c|c|c|c|c|c|c|c|c|c|c|c|c|c|c|c|c|c|}
\hline \multirow{2}{*}{$\begin{array}{l}\text { Lifeform } \\
\text { Kategori }\end{array}$} & \multicolumn{20}{|c|}{ Persentase Tutupan Karang (\%) } \\
\hline & $\mathrm{S} 1$ & $\mathrm{~S} 2$ & S3 & S4 & S5 & S6 & S7 & S8 & S9 & S10 & S11 & S12 & $\mathrm{S} 13$ & S14 & S15 & S16 & S17 & S18 & S19 & S20 \\
\hline $\begin{array}{l}\text { Acropora } \\
\text { Digitate }\end{array}$ & 5.5 & - & 0.5 & - & - & - & - & - & - & 3 & - & - & - & - & - & 1.5 & - & - & 1 & - \\
\hline $\begin{array}{l}\text { Acropora } \\
\text { Branching }\end{array}$ & 2.5 & 3.8 & 5 & 5.8 & 2.5 & 10 & 5.5 & 23 & 5 & - & 0.5 & 20 & 6.3 & 8.5 & 18.5 & 1 & 3.5 & - & 1.5 & 4.5 \\
\hline $\begin{array}{l}\text { Acropora } \\
\text { Tabulate }\end{array}$ & - & - & - & 8 & - & 7.5 & 8 & - & 4 & 5 & 8.5 & 6.5 & - & - & - & - & - & - & 4 & - \\
\hline $\begin{array}{l}\text { Acropora } \\
\text { Submassive }\end{array}$ & - & 0.5 & - & - & - & - & - & - & - & - & - & - & - & - & - & - & 0.5 & - & - & - \\
\hline Coral Massive & 6 & 9 & 9.5 & 7 & 9 & 15 & 1 & 8 & 13 & 15.5 & 15.5 & 14.5 & 25.5 & 16 & 9.5 & 2.5 & - & 9 & 13 & 5.5 \\
\hline Coral Foliose & - & 3.3 & - & 1 & 0.5 & 1 & 4 & - & - & - & 1 & - & - & - & - & - & - & - & - & - \\
\hline $\begin{array}{l}\text { Coral } \\
\text { Submassive }\end{array}$ & - & 3 & - & - & - & - & 3 & 2 & - & - & - & - & - & - & - & - & - & - & - & - \\
\hline $\begin{array}{l}\text { Coral } \\
\text { Branching }\end{array}$ & 4 & - & - & - & 0.5 & - & - & - & - & - & - & - & - & - & - & - & - & - & - & - \\
\hline $\begin{array}{l}\text { Coral } \\
\text { Encrusting }\end{array}$ & - & - & 22.8 & - & - & - & - & - & - & - & 2 & - & - & - & - & - & - & - & 9.5 & - \\
\hline $\begin{array}{l}\text { Coral } \\
\text { Mushroom }\end{array}$ & - & - & - & - & 0.8 & - & - & - & - & - & & - & - & - & 1 & 0.5 & - & - & - & - \\
\hline Persentase & 18 & 19.5 & 37.8 & 21.8 & 13.3 & 33.5 & 21.5 & 33 & 22 & 23.5 & 27.5 & 41 & 31.8 & 24.5 & 29 & 5.5 & 4 & 9 & 29 & 10 \\
\hline Rubble & 29 & 3.3 & 14 & 38 & 74.3 & 15 & - & 1.5 & 38.5 & 40.5 & - & 8 & 46.3 & 12 & 26.5 & 50.5 & 8 & 15.5 & 9.5 & 12 \\
\hline $\begin{array}{l}\text { Dead Coral } \\
\text { Algae }\end{array}$ & 37.5 & 67.3 & - & 17.3 & 11 & 41 & 67.5 & - & 28 & 36 & - & 33.5 & 1.5 & 2.5 & 13.5 & 34 & 73.5 & 26.5 & - & 0.5 \\
\hline Sand & 15.5 & 10 & 31.3 & 23 & 1.5 & 10.5 & 11 & 65.5 & 11.5 & - & 56 & 16 & 20.5 & 46 & 31 & 10 & 14.5 & 49 & 40 & 8.5 \\
\hline Rock & - & - & 16.5 & - & - & - & - & - & - & - & 16.5 & 1.5 & - & 15 & - & - & - & - & 21.5 & 69 \\
\hline $\begin{array}{l}\text { Kategori } \\
\text { Kondisi* }\end{array}$ & Brk & Brk & Sdg & Brk & Brk & Sdg & Brk & Brk & Brk & Brk & Sdg & Sdg & Sdg & Brk & Sdg & Brk & Brk & Brk & Sdg & Brk \\
\hline
\end{tabular}

* Kategori kerusakan terumbu karang berdasarkan Kepmen LH No. 4, Tahun 2001

Keterangan:

Brk : Rusak Buruk

Sdg : Rusak Sedang 